\title{
Platform-based sustainable business models: reducing food waste in food services
}

\section{Malla Mattila*, Nina Mesiranta and Anna Heikkinen}

\author{
Faculty of Management and Business, \\ Tampere University, \\ FI-33014, Finland \\ Email: malla.mattila@tuni.fi \\ Email: nina.mesiranta@tuni.fi \\ Email: anna.l.heikkinen@tuni.fi \\ *Corresponding author
}

\begin{abstract}
Food waste is a growing sustainability challenge for companies operating in the food services sector in developed countries. In this study, we examine how platform-based business models for food waste reduction can contribute to sustainability. We draw from the literature on business sustainability, sustainable business models (SBMs), and digital platforms, scrutinising two real-life business cases that provide digital services that help food service companies to reduce their food waste. Our findings identify the value network (user, producer, and support networks) and sustainable value proposition (economic, environmental, and social dimensions) as key elements for addressing sustainability in platform-based businesses. The study contributes to the SBM literature by developing an empirical and systemic understanding of platform-based SBMs. The cases illustrate that these SBMs have the potential to contribute to sustainability through scalability and attractiveness. From a managerial standpoint, the study offers companies insights into how to develop sustainability in their business operations.
\end{abstract}

Keywords: sustainability; sustainable business model; platform; digital; food service; restaurant; food waste; food waste reduction; business model; value network; value proposition; digital service; application; case study; innovation.

Reference to this paper should be made as follows: Mattila, M., Mesiranta, N. and Heikkinen, A. (2020) 'Platform-based sustainable business models: reducing food waste in food services', Int. J. Entrepreneurship and Innovation Management, Vol. 24, Nos. 4/5, pp.249-265.

Biographical notes: Malla Mattila works as a Senior Lecturer (Master’s degree Program in Leadership for Change) in the Faculty of Management and Business, Tampere University, Finland. Her research interests include food waste reduction, sustainable business models, networked technology commercialisation, and sociomateriality. She has published her research in scholarly periodicals such as the Journal of Cleaner Production, Time \& Society, IMP Journal, International Journal of Entrepreneurship and Innovation Management, and South Asian Journal of Business and Management Cases. She is also a co-editor of the book Food Waste Management: Solving the Wicked Problem, published by Palgrave Macmillan. 
Nina Mesiranta is currently working as a Postdoctoral Researcher in the Wastebusters research project, focusing on food waste reduction, in the Faculty of Management and Business, Tampere University, Finland. Her research interests are food waste reduction, digital services and online business models, online shopping, and social media. Her work has been published in edited volumes and journals, such as the Journal of Cleaner Production, Time \& Society, Journal of Retailing and Consumer Services, Journal of Fashion Marketing and Management and Advances in Consumer Research. She is also a co-editor of the book Food Waste Management: Solving the Wicked Problem, published by Palgrave Macmillan.

Anna Heikkinen is a Lecturer (Management and Organisation) in the Faculty of Management and Business, Tampere University, Finland. She holds a title of Docent in Business Ethics and Sustainability (University of Eastern Finland, Finland). Her research interests are corporate sustainability and stakeholder theory, urban sustainability, and the relationships between business organisations and society. Her work has been published in edited volumes and journals, such as the Journal of Business Ethics, Business Communication Quarterly and International Journal of Knowledge Management Studies. She is also a co-editor of the book Food Waste Management: Solving the Wicked Problem, published by Palgrave Macmillan.

This paper is a revised and expanded version of a paper entitled 'Creating value from food waste: case ResQ Club' presented at the International Conference on Management Cases, New Delhi, India, 30 November to 1 December 2017.

\section{Introduction}

Food waste, simply defined as edible food lost during all stages of food production and consumption (Baron et al., 2018; Östergren et al., 2014), is a pressing sustainability challenge and a ‘wicked problem' (Närvänen et al., 2019). Globally, one-third of food produced for human nutrition is lost or wasted, amounting to about 1.3 billion tonnes per year (FAO, 2011). The carbon footprint of food waste is about $4.4 \mathrm{Gt} \mathrm{CO}_{2}$ eq per year, nearly equalling road transport emissions (FAO, 2015). The direct cost of food waste is estimated to be USD 1 trillion each year (FAO, 2017). While food waste occurs throughout all phases of the food supply chain in developed countries, the later stages (i.e., households) contribute the most waste (e.g., Parfitt et al., 2010; Priefer et al., 2016; Stenmarck et al., 2016). Recent research has started to focus on the emergence of food waste in the food services sector - that is, restaurants, cafés, and canteens, as well as catering and accommodation services (Betz et al., 2015; Heikkilä et al., 2016; Papargyropoulou et al., 2016; Pirani and Arafat, 2016; Silvennoinen et al., 2015). For example, Marthinsen et al. (2012) estimated that the hospitality sector in the four Nordic countries (Denmark, Finland, Norway and Sweden) generates 680,000 tonnes of food waste annually, of which 456,000 tonnes is avoidable.

This study addresses food waste reduction in food services in Finland and seeks to answer the following research question: How can platform-based business models for food waste reduction contribute to sustainability? The study builds upon the literature on business sustainability, sustainable business models (SBMs), and digital platforms. The business sustainability literature highlights how companies can contribute to 
societal-level sustainability objectives by integrating economic, environmental, and social aims while balancing the various stakeholder interests involved in their operations (Bansal, 2002; Dyllick and Hockerts, 2002; Hahn et al., 2015; Hörisch et al., 2014). The growing body of literature on SBMs - also referred to as business models for sustainability (Abdelkafi and Täuscher, 2016; Schaltegger et al., 2016) or green business models (Beltramello et al., 2013; Høgevold, 2011; Sommer, 2012) - investigates possibilities for utilising the business model concept to incorporate sustainability into a company's value creation and value capture logics (Lüdeke-Freund and Dembek, 2017). Previous research on SBMs has presented frameworks for categorising SBMs and conceptualising different elements (Abdelkafi and Täuscher, 2016; Bocken et al., 2014; Schaltegger et al., 2016). However, empirical research on SBMs in general (Gauthier and Gilomen, 2016; Roome and Louche, 2016) and food waste reduction in particular remains scarce (for an exception, see Ribeiro et al., 2018).

Furthermore, to identify solutions to the increasing food waste problem, food service companies have started to explore the possibilities offered by digitalisation. Digital platforms (such as online applications and internal reporting and measurement systems) provide numerous opportunities, including the more efficient use of various natural resources and methods of diminishing waste-related costs (Marthinsen et al., 2012; Mattila et al., 2018). However, empirical studies on digital platforms remain scarce because the issue is new, and it is difficult to obtain the relevant data (Schor and Attwood-Charles, 2017). These two gaps in the literature - the lack of empirical studies on both SBMs and digital platforms - are the impetus for this study.

We present a qualitative, multiple-case study of two Finnish digital platforms that tackle the problem of food waste in food services by facilitating transactions between individuals and organisations. The first is the Hävikkimestari application, hereafter called Waste Master (the unofficial translation of the authors). Waste Master aims to reduce food waste in all three phases of the service (kitchen, serving, and plate waste) and focuses on producing data on internal processes. The second application is ResQ Club, which offers an alternative outlet for surplus food on a digital platform that connects consumers and restaurants, thus specifically tackling serving waste. The generated qualitative research data are composed of interviews, documents, and YouTube videos. The findings of the analysis identify the value network and sustainable value proposition as key elements for addressing sustainability in platform-based business models in food services.

Utilising the three aforementioned streams of literature (business sustainability, SBMs, and digital platforms) and two real-life business cases, the study makes the following contributions to the SBM literature. First, it increases the empirical and systemic understanding of platform-based SBMs, which have remained an under-investigated research area. We argue that the value network and value proposition are the key elements through which sustainability is addressed in the platform-based business models for food waste reduction. Second, our cases demonstrate that platform-based SBMs have the potential to contribute to sustainability in society. This study concludes that platform-based SBMs can increase social and intergenerational justice by reducing or preventing food waste and by providing long-term solutions that are attractive, scalable, and transferable to other contexts and issues.

First, the article discusses the literature on sustainable development and business sustainability, SBMs, and digital platforms to provide the conceptual groundwork for the 
study. Second, we explain the research context, cases, and generated data, as well as the process of data analysis and interpretation. Third, we present the findings on value networks and sustainable value propositions. Finally, there is a discussion of the findings and conclusions, as well as the limitations of the study and its future research paths.

\section{Theoretical framework}

\subsection{Sustainable development and business sustainability}

Sustainable development is commonly defined as development that "meets the needs of the present without compromising the ability of future generations to meet their own needs" [WCED, (1987), p.8]. Typically, sustainability is conceptualised according to three dimensions: economic and social development, and environmental protection (United Nations, 2002). Accordingly, business sustainability can be defined as "meeting the needs of a firm's direct and indirect stakeholders (such as shareholders, employees, pressure groups, communities, etc.), without compromising the ability to meet the needs of future stakeholders as well” [Dyllick and Hockerts, (2002), p.131].

Business sustainability is based on three premises (e.g., Bansal and Song, 2017; Hahn et al., 2015). First, sustainability means pursuing economic, environmental, and social dimensions simultaneously. In business, instrumental logic and the economic dimension are often prioritised. Situations in which tensions exist regarding how to best align social or environmental aspects with economic goals are often dismissed. Disregarding these tensions is problematic because it fosters the typically instrumental win-win logic and business-as-usual practices that are inevitably limited in pursuing sustainability (Hahn et al., 2010). Thus, addressing sustainability requires the acceptance of tensions and uncertainty (Hahn et al., 2015).

Second, sustainability emphasises intergenerational fairness and desirable outcomes at the societal level. Sustainable development is a societal and system-level concept that addresses the sustainability of social systems in terms of economic, environmental, and social well-being and development (Bansal, 2002; Dyllick and Hockerts, 2002). Thus, business sustainability considers companies as drivers and enablers of sustainable development within society because they have the resources to do so. The aim of business sustainability, therefore, is for companies to contribute to societal-level objectives and achieve sustainable organisational outcomes (Bansal, 2002; Bansal and DesJardine, 2014). The intergenerational perspective denotes that the economic, environmental, and social dimensions need to be balanced over time (Bansal and DesJardine, 2014), and it values long-term solutions and benefits over short-term returns.

Third, sustainability includes the recognition and balancing of various and even conflicting stakeholder interests (Hahn et al., 2015; Hörisch et al., 2014). In the context of sustainability management, the aim is to foster sustainability as a key value and a common interest in stakeholder collaboration. This requires the enhancement of the stakeholders' sustainability interests and the identification of common interests (Hörisch et al., 2014). However, compromise and even trade-offs are inevitable in these processes (Sharma and Kearins, 2011). Hörisch et al. (2014) noted that focusing on the ways in which trade-offs can be overcome is more purposeful than avoiding conflicts in the first place. 


\title{
2.2 Sustainable business models
}

A growing body of research on SBMs has sought to transform the traditional view of business models by emphasising the multiple opportunities for combining economic profitability with social and environmental value creation (e.g., Boons et al., 2013; Lüdeke-Freund and Dembek, 2017; Schaltegger et al., 2012; Schaltegger et al., 2016). SBM research includes studies on business model patterns and archetypes (Abdelkafi et al., 2013; Bocken et al., 2014). For instance, Bocken et al. (2014) categorised eight SBM archetypes within three broader groupings: technological (material energy efficiency maximisation, value creation from 'waste' and renewables, and natural processes substitution), social (delivery of functionality rather than ownership, stewardship role adoption, and sufficiency encouragement), and organisational (societal/environmental repurpose and scale-up solutions development). Furthermore, previous research has focused on the interconnections between sustainability strategy and business models (Schaltegger et al., 2012; Schaltegger et al., 2016). This stream of research highlights how these models incorporate and balance environmental, social, and economic aims, alongside the view that sustainability is a strategy and not an addition to strategy (Schaltegger et al., 2016). In addition, previous research has suggested that technological innovation alone cannot address sustainability, because it is a systemic and multilayered issue (Geels, 2010).

In this paper, we adopt the following definition of the SBM:

\begin{abstract}
A business model for sustainability helps describing, analysing, managing, and communicating (i) a company's sustainable value proposition to its customers, and all other stakeholders, (ii) how it creates and delivers this value, (iii) and how it captures economic value while maintaining or regenerating natural, social, and economic capital beyond its organizational boundaries. [Schaltegger et al., (2016), p.6]
\end{abstract}

This definition emphasises that sustainability is an integral part of a company's value creation and capture logics. It expands the traditional, firm-centric business model perspective by focusing on stakeholders, such as investors, managers, employees, and customers.

Furthermore, the previous literature has presented the core elements of an SBM (Abdelkafi and Täuscher, 2016; Boons and Lüdeke-Freund, 2013; Schaltegger et al., 2016). The first core element is a sustainable value proposition, which concerns the value exchange relationships between a company, its customers, and other stakeholders (Schaltegger et al., 2016). Within the SBM, this means that companies provide environmental, social, and economic value through their offerings (Boons and Lüdeke-Freund, 2013). The second core element is the business infrastructure (upstream relationships, i.e., suppliers), and the third is the customer interface (downstream relationships, i.e., customers) (Boons and Lüdeke-Freund, 2013). Previous research has argued that sustainability principles should be integrated into both production and consumption networks (Lacoste, 2016). Companies can no longer act alone or are incapable of addressing sustainability issues by themselves. Instead, they are interdependent, which shapes their activities, performances, and sustainability (Loorbach et al., 2010). The fourth core element is the financial model distributing the economic costs and benefits (equitably) among the actors involved (Boons and Lüdeke-Freund, 2013) while contributing to sustainability in society (Schaltegger et al., 2016). 


\subsection{Digital platforms}

Digital platforms, which emerge from and are supported by technology, interacting organisations, and individuals (Gawer, 2014; Gawer and Cusumano, 2014), are closely connected with business models as a novel context for opportunity discovery, business model shaping, and competition (Teece, 2009). Previous research on platforms was developed from the perspectives of management and organisation (platforms as technological designs) and economics (platforms as vehicles for structuring markets and influencing transactions) (for a review, see Gawer, 2014). Efforts have also been made to integrate these two views. Gawer (2014), for instance, proposed that platforms should be seen as evolving (meta-)organisations that join and coordinate actors, create value by utilising economies of scope in supply and/or in demand, and include a core-periphery structure. In this respect, Gawer (2014) located and distinguished platforms within three broader settings: within firms (internal platforms involving one company, closed interfaces), across supply chains (supply chain platforms involving an assembler and suppliers, selectively open interfaces), and across industry ecosystems (industry platforms involving a platform leader and complementors, open interfaces).

This study focuses on the levels of firms and supply chains and, more specifically, on digital platforms as transaction platforms (Evans and Gawer, 2016). Well-known examples of transaction platforms are Über, Airbnb, eBay, and Netflix. Previous business sustainability research has shown that transaction platforms such as Airbnb foster sustainability in terms of social connections but might simultaneously have unsustainable elements - for example, the promotion of air travel and inequalities, such as racial discrimination (Schor and Attwood-Charles, 2017). Here, we focus on two digital platforms that facilitate transactions between different actors (individuals and organisations) to reduce food waste in food services.

\section{Methodology}

\subsection{Research context and cases}

Our study focuses on the reduction of food waste within food services. In Finland, where this study was conducted, total food waste varies between $19 \%$ and $27 \%$ of all food prepared, depending on the type of food service (Silvennoinen et al., 2015). It has been estimated that in Finland, this amounts to 75-85 million kilograms of avoidable food waste per year or 14-16 kilograms per year per capita (Katajajuuri et al., 2014). Food waste emerges in three phases in food services: as kitchen, serving, and plate waste (Silvennoinen et al., 2015). First, during cooking and food preparation, food waste occurs in the kitchen, for example, due to spoilage or incorrect preparation. Second, serving waste occurs when food is already cooked and prepared but never reaches customers' plates. This happens, for example, due to the overproduction of food, especially at self-service buffet restaurants. Serving waste has been identified in several studies as the main source of avoidable food waste (Betz et al., 2015; Eriksson et al., 2017; Pirani and Arafat, 2016; Silvennoinen et al., 2015). Finally, plate waste emerges when customers leave food uneaten.

We adopted a qualitative, multiple-case study research design (Eriksson and Kovalainen, 2016; Stake, 2005), thereby enabling us to identify the key elements of the 
platform-based business models. We chose two real-life Finnish business cases that aim to reduce food waste in food services with the help of digital platforms: Waste Master and ResQ Club. These businesses are well known and established in Finland. They were selected because we expected them to provide an opportunity for us to acquire extensive knowledge of this research phenomenon (Stake, 2005).

The Waste Master application helps to reduce food waste by improving internal processes in food services. It calculates and visualises the amount of food waste in the restaurant and provides information about its causes. Restaurant employees weigh the food waste and then use the application to record the amount and the reason for the waste; consequently, information about food waste is available in real time for all personnel. The application was launched by Lassila \& Tikanoja (L\&T) in 2016 as an internal digital experiment. L\&T, an international corporation focusing on environmental management and support services for properties and plants, operates in Finland, Sweden, and Russia and has 8,500 employees. According to L\&T, since introducing Waste Master, food service outlets have succeeded in reducing their food waste by $30 \%$ to $50 \%$. Waste Master's financial model is based on licensing revenues gained from using the application and coaching customers' personnel to reduce their food waste. In addition, as an internal experiment, Waste Master receives financial and other resources from the main company (L\&T).

ResQ Club, a Finnish start-up founded in late 2015, provides a digital service aimed at reducing food waste, especially serving waste, in restaurants. Using this online application, restaurants can sell their leftover meals after lunchtime to consumers at a discount. The participating restaurants register meal portions on the application and then set a price and a timeline for picking up the meals. Customers can download the application free of charge. Using the application, consumers can choose a meal according to their preferences and make a payment to the restaurant. The mission of ResQ Club is to create societies that are free of food waste, and the first step is to eliminate serving waste from restaurants in Europe by 2030. The company currently operates in 60 cities in Finland. It sought growth through two offshore mergers (Meal Saver, Germany and Rädda Maten, Sweden) and began operating in 15 cities in Sweden and two in Germany. In 2018, the application 'rescued' approximately 700,000 meals, equalling about $1,750,000$ kilograms of $\mathrm{CO}_{2}$ emissions. ResQ Club's financial model is based on commissions from each meal sold through the application. Thus, the company is dependent on the emergence and existence of restaurant food waste. The business operations have also been dependent on external funding in the form of public investors, such as Business Finland, and private angel investors.

\subsection{Data generation and analysis}

The study is based on primary and secondary data. The primary data comprised semi-structured interviews, and the secondary data included company and media documents as well as YouTube videos. Waste Master data were generated in November and December 2017. The data consisted of two interviews with company representatives (I1 and I2), one with a customer (I3), and approximately 100 pages of documents downloaded from the Internet, including company bulletins and news about the application. The ResQ Club data were generated on three occasions: in October and November 2016, while generating the Waste Master data, and in February and April 
2018. The data consisted of interviews with five company representatives (I4-I8), seven restaurant representatives (I9-I15), and three consumers (I16-I18), as well as approximately 134 pages of documentary data downloaded from the Internet, including news about the application and the start-up. We also collected 13 ResQ Club-related videos from YouTube. The interview data totalled 11 hours and 19 minutes, and all interviews were transcribed verbatim.

The primary data were analysed using the qualitative content analysis method (Elo and Kyngäs, 2008). To become familiar with the generated data, all authors read through the texts individually. The next phases of the data analysis proceeded collaboratively and were characterised by deduction - that is, determining whether and how the core elements of the SBM concept apply in our context. However, we modified the core elements to better fit our cases. First, we analysed the value network in our data by identifying the key actors for whom value is created. The value network in our findings contains both the business infrastructure and customer interface elements (user, producer, and support networks). We then analysed the sustainable value proposition by explicating the kind of value that is created. This sustainable value proposition includes the economic, environmental, and social dimensions of sustainability, which are interrelated. However, for analytical purposes, we elaborate on them separately in our findings. Secondary data were utilised to contextualise the cases and to supplement the data analysis and interpretation. Next, we present our findings concerning the value network and sustainable value proposition, as well as their connection to sustainability.

\section{Findings}

\subsection{Value network}

We identified three main types of networks that are critical for creating and capturing value from food waste in food services: the user network, producer network, and support network.

The user network includes those actors in the value network who use the digital platform and for whom it has the potential to create value. In both empirical cases, two user groups that are connected via the digital platform can be identified. For Waste Master, the user network consists of food service personnel from managers to kitchen workers. These personnel can be divided into two types: those who enter data into the application and those who utilise it in their daily work or as part of the organisation's long-range planning and reporting. The kitchen staff is mainly responsible for weighing the food waste produced and entering the data into the application. The users - both the manager-level personnel and the same kitchen personnel who entered the data - utilise the visualised data from the application to develop internal processes to reduce and prevent food waste.

For ResQ Club, the user network comprises restaurants and consumers whom the company's platform connects. However, this creates challenges for ResQ Club, as it has to be aware of the needs and wishes of both sides. To do this efficiently, ResQ Club has divided its platform in such a way that restaurants and consumers use two different applications. The restaurant personnel enter the leftover meals into the application, which only they can see. In this application, they describe the contents of the leftover meal, include 'tags' (i.e., required information, such as the ingredients), a price, and when the 
meal can be collected. This information then appears in a different mobile application used by the consumers.

The producer network comprises the internal L\&T and ResQ Club workforces that are essential to the platforms. In both cases, the producer network includes the technical personnel who are responsible for digital platform maintenance and technical development, as well as the personnel who are responsible for sales, marketing, and product development.

Waste Master is located within L\&T's environmental services team. As a provider of waste management services, L\&T can sell the Waste Master application to its existing customers. However, as an easily scalable digital service, Waste Master has the potential to attract new customers, enabling L\&T to expand its business from local to international waste management. L\&T has established a separate digital team that is responsible for the technical development and maintenance of all of its recent digital experiments, including those related to Waste Master.

The ResQ Club's producer network sells and markets the digital service by participating in fora and events through which it can reach potential customers for the user network and critical parties for the support network. These events include festivals and other occasions organised around sustainable food production and consumption, as well as cooperative projects organised collaboratively with parties from the support network, such as the Zadaa marketplace application. The producer network also develops the applications involved in the platform according to the customer feedback.

The support network involves those parties that assist in value creation and value capture. As an internal experiment of a long-established company, Waste Master's support network consists of internal support provided by L\&T, including financial resources. Conversely, ResQ Club's support network is external to the company and consists of two main actor groups, the first of which is composed of financing parties; as a start-up, ResQ Club requires external funding to run its business operations. The second comprises ResQ Club's cooperative parties, which consist primarily of suppliers and subcontractors who assist the company with marketing, advertising, programming, and business planning, among other areas.

\subsection{Sustainable value proposition}

The sustainable value proposition includes the economic, environmental, and social dimensions. The economic dimension concerns cost reductions, creating new business opportunities and income from waste, improving brand image, and acquiring new customers. Waste Master's value proposition is based on providing visualised information about food waste-related processes for all parties involved in the food service outlet. The data produced in the application enables users to detect what, where, and when food is wasted. This visualisation allows the food service personnel to innovate and discuss possible solutions to reduce food waste, as described in the following interview excerpt:

One particular type of innovation related to this is how the employees themselves - who know their everyday lives [and] their customers best - start to develop their own processes, thinking about what we could do differently to avoid this type of food waste. (I2, L\&T company representative) 
Restaurant customers who use the applications have been successfully reducing their food waste and the cost of waste management. Costs can also be reduced because internal processes become optimised for food waste reduction, affecting, for example, the purchase of raw materials. The applications can enhance the customers' brands, as they provide either data about food waste reduction or otherwise show their sustainable practices. Lower costs and savings are illustrated as follows:

In 2016, our bio waste amounted to 2,000 tonnes - that is, two million kilos. [...] On the one hand, we are talking about really big amounts of food and, on the other hand, about really big sums of money that end up in the trash. To handle that much [waste] costs ' $X$ ' euros; plus, it includes ingredients and pretty much includes work, too. [...] This system [Waste Master] has made visible those euros and grams or kilos or tonnes or hundreds of tonnes [of waste]. (I3, company representative for a Waste Master customer)

We create economic value by reducing waste. Restaurants can buy fewer ingredients, meaning cost savings that they can invest in wherever they want. That is, buy better ingredients, or leave it below the line or whatever. [...] It is also a good selling point for us that we can create concrete savings. (I1, L\&T company representative)

ResQ Club has two main customer groups: restaurants and consumers. The application enables the restaurants to reduce serving waste and turn the cost of food that would be otherwise wasted into profit. The application also helps introduce new customers to the participating restaurants in a low-cost and easy-to-access way, whereby customers face minimal risk in trying new restaurants or meals.

When we have put those [products in the glass display case] up for sale through ResQ [Club], often the customers buying them from us are not necessarily related in any way to our normal daily customer base; so, we have most likely gained totally new customers. ResQ [Club] is not only a tool to save these products, but I think it is also a tool for marketing our responsible actions in a positive way. (I9, customer representative of a ResQ Club restaurant)

The application brings more customers to the restaurant's physical location, which might encourage them to visit the restaurant again. For the consumers, the application offers economic benefits, as they are able to purchase restaurant meals cheaper than their 'usual' prices. The consumers can also save time, as they do not need to cook.

The environmental dimension includes the more efficient use of natural resources, as well as the reduction of carbon dioxide and other harmful emissions due to less waste ending up in landfills. The reduction of food waste through the applications has important environmental benefits both within and beyond the restaurant. Food production and preparation have significant environmental footprints and produce harmful emissions because they use various resources, such as nutrients, water, and energy, which are wasted when produced and prepared food is discarded. The environmental benefits and saved resources were emphasised in the interviews:

Well, of course there are these environmental benefits. I mean, it is good for all of us if less food is thrown in the bin. And then, restaurants can also utilise that in their [marketing] communication, but it also helps them to achieve their sustainability and environmental objectives. (I1, L\&T company representative)

Our intention is to stop wasting food so that we can make the planet a better place to live on. [...] We want people to be able to utilise the ingredients that would otherwise end up as waste. (I7, ResQ Club company representative) 
The main difference between the Waste Master and ResQ Club value propositions revolves around the type of waste being reduced. Waste Master enables the monitoring of all three types of food waste in food services, thereby indicating the potential for food waste reduction throughout the process of preparing and serving the food. In contrast, ResQ Club focuses on decreasing serving waste at participating restaurants. Both enable consumers to make more environmentally responsible choices in their everyday lives either by being prompted to put less food on their plates at buffets (Waste Master) or by saving leftovers to prevent food from ending up as waste (ResQ Club).

The social dimension focuses on creating equality and justice for consumers and employees and increasing awareness of the problem of food waste in society. The applications can increase the meaningfulness of work in food services and in restaurants, as they provide concrete methods of reducing food waste by modifying food preparation and serving processes. Moreover, ResQ Club provides access to quality food at a low price, thereby offering more equal opportunities for low-income consumers to purchase food from restaurants. This promotes social balance and societal well-being, as described in the following quotation:

And then there is also another sustainability issue, as many people really cannot afford to go to a restaurant and eat restaurant food. We now offer them an opportunity to eat food that somebody else has made, at the cost of basic ingredients. (I7, ResQ Club company representative)

\section{Concluding discussion}

This study addressed food waste reduction in food services. We sought to answer the question of how platform-based business models for food waste reduction can contribute to sustainability. The study contributes to the SBM literature by developing an empirical and systemic understanding of platform-based SBMs and their potential for contributing to sustainability.

Conceptually, our study relied on the business sustainability, SBM, and digital platform literature. Business sustainability is based on three premises:

1 the integration of economic, environmental, and social dimensions

2 societal-level outcomes and intergenerational fairness

3 the balancing of stakeholder interests (Bansal, 2002; Dyllick and Hockerts, 2002;

Hahn et al., 2015; Hörisch et al., 2014).

SBMs seek to incorporate sustainability into companies' value creation and capture logics (e.g., Lüdeke-Freund and Dembek, 2017). Digital platforms are a novel context for business opportunity discovery and development (Evans and Gawer, 2016) and for researching various aspects of sustainability (see Schor and Attwood-Charles, 2017).

Empirically, we analysed two real-life Finnish business cases (Waste Master and ResQ Club) that aim to reduce food waste in the food services sector with the help of digital platforms. The analysis focused on the modified core elements of the SBM concept (compare with Boons and Lüdeke-Freund, 2013): the financial model, value proposition, and value network. Below, we summarise and reflect on the key findings of the study (see Figure 1). 
Figure 1 Summary of the findings

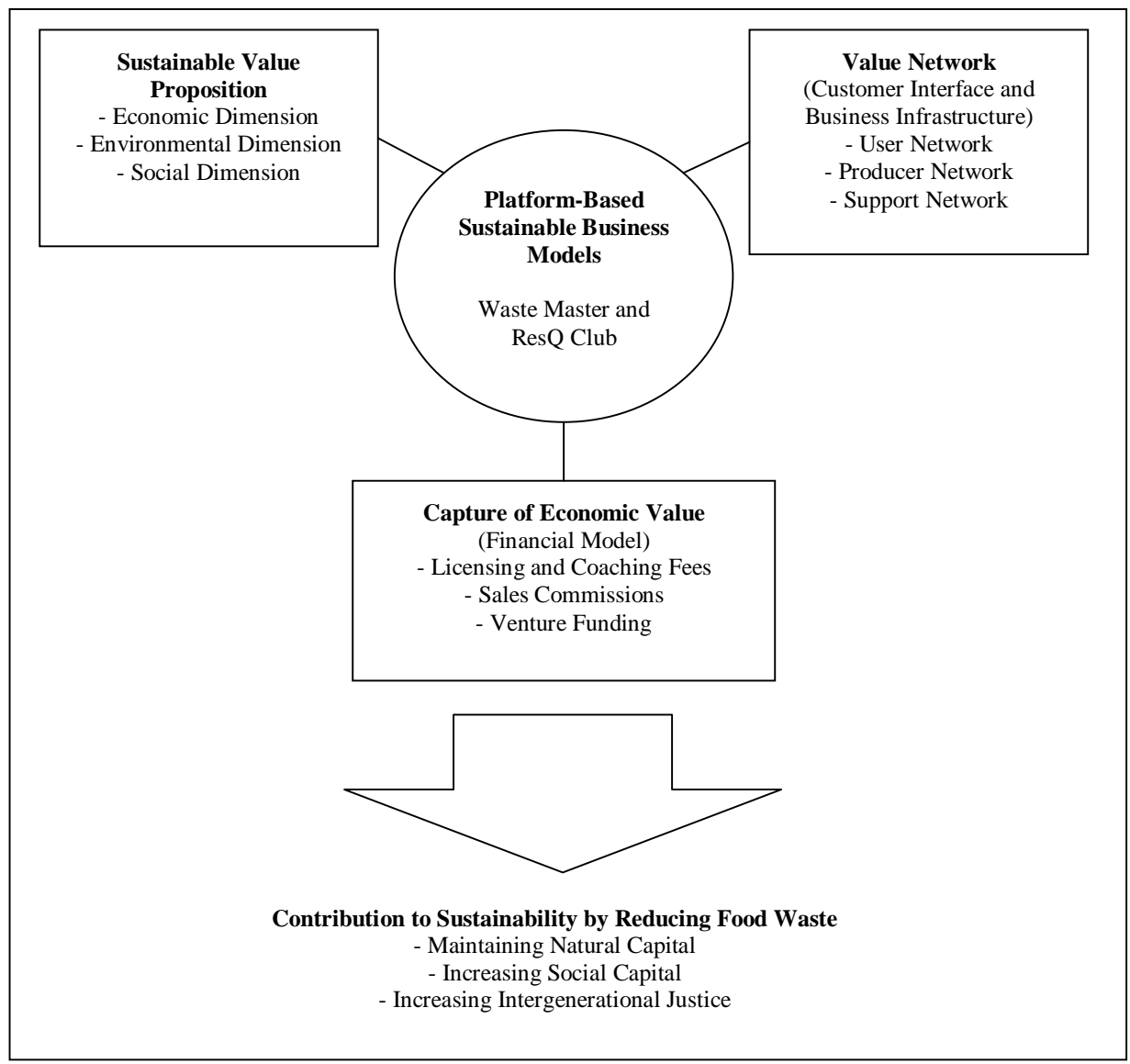

Our findings demonstrate that a platform-based business model is suitable for addressing sustainability. The value network comprises three key networks: user, producer, and support. The user network concerns those who use the digital platform and for whom it has potential to create value (the food service and restaurant personnel and consumers). The producer network involves the internal workforce, which is responsible for technical issues, sales, marketing, and platform development. The support network consists of various internal and external actors who provide additional resources for business operations. This study concludes that while all contributors are important in creating and capturing value from food waste in a platform-based SBM, the most critical is the user network.

In platform-based SBMs, the underlying sustainable value propositions are intertwined with economic, environmental, and social aspects of sustainability (Boons et al., 2013; Lüdeke-Freund and Dembek, 2017; Schaltegger et al., 2012; Schaltegger et al., 2016). Our findings demonstrate that the economic dimension focuses on reducing costs, creating revenue from waste, enhancing brand image, and finding new customers. The environmental dimension involves paying attention to the more efficient use of 
natural resources and, thus, reducing environmentally harmful emissions from waste. The social dimension revolves around equality and justice for different stakeholder groups and increasing awareness of the food waste issue in society. The financial models consist of licensing and coaching fees, sales commissions, and/or venture funding. While tensions and uncertainty are inherent to sustainability (Hahn et al., 2015), these issues were not raised in our cases. There are at least two possible reasons for this. First, as sustainability was integrated into the cases from the beginning, the operations were designed to align the three dimensions of sustainability. Furthermore, this alignment reduced uncertainty related to sustainability aspects. Second, while internal tensions were not brought up by our interviewees, the generation of data from other stakeholders (e.g., investors, non-governmental organisations, and local communities) might provide more insights into the tensions and trade-offs.

We argue that the value network and the sustainable value proposition are the key elements through which sustainability is addressed in the platform-based businesses that are emerging around the increasing challenge of food waste in food services. The digital platform helps to bring together various stakeholder groups, such as citizens (consumers), employees, and business professionals, who are keen to address this social problem and who might otherwise remain unconnected (Evans and Gawer, 2016). These groups can contribute to the creation of a sustainable society by 'rescuing' food and preventing it from being sent to landfill. Wasting food is harmful to the environment and diminishes opportunities for social balance and societal well-being. While stakeholder groups engage in collaborative activities to prevent food waste, they are able to make extra earnings or save money. Thus, digital platforms highlight the importance of network relationships in sustainable business (see also Lacoste, 2016).

In regard to sustainability, tensions often arise between different stakeholder groups because of their different ideologies and tendencies to preserve their self-interests (Sharma and Kearins, 2011). The digital platforms for reducing food waste provide opportunities for different stakeholders to work collaboratively towards achieving sustainability. Thus, these applications can be described as cases that foster joint stakeholder interests (Hörisch et al., 2014), at least between the customers and restaurants that use them. Over time, tensions might arise when the sustainability interests of particular groups change.

Furthermore, previous research on sustainable business has argued that achieving sustainability requires mass markets to become more sustainable and that companies have a crucial role in enabling these changes (Schaltegger et al., 2016). By providing easy-to-access, resource- efficient, and scalable online applications, the cases indicate the potential of digital platforms to make mass markets more sustainable. First, sustainability as a core issue on these platforms makes them attractive for new users. Second, the easy scalability of the business models can attract more users, thereby offering greater transformative potential.

As technological innovations, digital applications such as Waste Master or ResQ Club alone cannot create change towards sustainability in society (see also Boons and Lüdeke-Freund, 2013; Geels, 2010). However, similar applications geared towards tackling food waste indicate the potential for sustainable value creation and value capture. For example, Olio in the UK works with a logic that is similar to ResQ Club's 
but targets surplus food in households. The NoFoodWasted application in the Netherlands connects supermarkets and consumers to facilitate the sale of products that are about to expire. Furthermore, combining the operational logics of Waste Master and ResQ Club would yield a more substantial effect that would, for example, allow for the automatisation of selling potential serving waste to customers. As examples of digital (for-profit) platforms for sustainability, the cases are private and closed. Gawer (2014) argued that closed platforms may broaden their scope to become more open. Thus, the development of a similar type of open-access, multi-sided platform would benefit society at large.

Digital platforms make often-invisible food waste more visible in society. In an increasingly digitalised society, data play a crucial role in sustainability. Although it is impossible to digitalise food or food waste as matter, digitalisation enables the production of data that help in monitoring the amount and, consequently, the reduction of food waste. Through this real-time data production, those engaging in food waste-related practices in their daily work in food services can become more motivated and dedicated to innovating new practices for food waste reduction (see also Buhl, 2018).

Our cases illustrate that platform-based SBMs have significant potential to contribute to sustainability at the societal level. They can increase social justice by fostering collaboration among citizens (consumers), businesses, and other stakeholders, as well as by sharing and caring for others and the environment (Landrum, 2017). In terms of intergenerational justice, platform-based SBMs seek to balance the use of natural resources by reducing and preventing waste and by providing long-term scalable solutions. Platform-based solutions are also transferable to other issues of waste in society.

Regarding limitations, the use of only two empirical business cases inevitably limits the ability to generalise the findings. However, the study provides four avenues for future research. The first area of future investigation relates to other examples of platform-based SBMs. An analysis of platform-based SBMs that address sustainability challenges similar to food waste would be an important contribution. The second area concerns digital platform development opportunities from the business sustainability viewpoint, and the third involves the (dynamic) capabilities that enable and/or hinder platform-based SBM development. Finally, future research could focus on the empirical examination of the emerging tensions and trade-offs related to sustainability views and how they are managed while designing and/or actualising platform-based SBMs.

\section{Acknowledgements}

This study was conducted as part of research project 'Consumer-citizens as active reducers of food waste' funded by Emil Aaltonen Foundation, Finland and Finnish Foundation for Economic Education. We also wish to acknowledge financial support from the Academy of Finland (decision number 298663) and the Strategic Research Council at the Academy of Finland (decision numbers 320194 and 320206). 


\section{References}

Abdelkafi, N. and Täuscher, K. (2016) 'Business models for sustainability from a system dynamics perspective’, Organization \& Environment, Vol. 29, No. 1, pp.74-96.

Abdelkafi, N., Makhotin, S. and Posselt, T. (2013) 'Business model innovations for electric mobility - what can be learned from existing business model patterns?', International Journal of Innovation Management, Vol. 17, No. 1, p.1340003 [online] https://www.worldscientific.com/doi/pdf/10.1142/S1363919613400033 (accessed 26 October 2018).

Bansal, P. (2002) 'The corporate challenges of sustainable development', Academy of Management Executive, Vol. 16, No. 2, pp.122-131.

Bansal, P. and DesJardine, M.R. (2014) 'Business sustainability: it is about time', Strategic Organization, Vol. 12, No. 1, pp.70-78.

Bansal, P. and Song, H.C. (2017) 'Similar but not the same: differentiating corporate sustainability from corporate responsibility', Academy of Management Annals, Vol. 11, No. 1, pp.105-149.

Baron, S., Patterson, A., Maull, R. and Warnaby, G. (2018) 'Service ecosystem perspective on innovative food waste reduction', Journal of Service Research, Vol. 21, No. 1, pp.135-150.

Beltramello, A., Haie-Fayle, L. and Pilat, D. (2013) Why New Business Models Matter for Green Growth, OECD Green Growth Papers, 2013-01, OECD Publishing, Paris, France [online] https://doi.org/10.1787/5k97gk40v3ln-en (accessed 21 January 2019).

Betz, A., Buchli, J., Göbel, C. and Müller, C. (2015) 'Food waste in the Swiss food service industry - magnitude and potential for reduction', Waste Management, Vol. 35, pp.218-226.

Bocken, N.M.P., Short, S.W., Rana, P. and Evans, S. (2014) 'A literature and practice review to develop sustainable business model archetypes', Journal of Cleaner Production, Vol. 65, pp.42-56.

Boons, F. and Lüdeke-Freund, F. (2013) 'Business models for sustainable innovation: state-of-the-art and steps towards a research agenda', Journal of Cleaner Production, Vol. 45, pp.9-19.

Boons, F., Montalvo, C., Quist, J. and Wagner, M. (2013) 'Sustainable innovation, business models and economic performance: an overview', Journal of Cleaner Production, Vol. 45, pp.1-8.

Buhl, A. (2018) 'Do it yourself - a lean startup toolbox for employee-driven green product innovation', International Journal of Entrepreneurship and Innovation Management, Vol. 22, Nos. 4-5, pp.526-544.

Dyllick, T. and Hockerts, K. (2002) 'Beyond the business case for corporate sustainability', Business Strategy and the Environment, Vol. 11, No. 2, pp.130-141.

Elo, S. and Kyngäs, H. (2008) 'The qualitative content analysis process', Journal of Advanced Nursing, Vol. 62, No. 1, pp.107-115.

Eriksson, M., Persson Osowski, C., Malefors, C., Björkman, J. and Eriksson, E. (2017) 'Quantification of food waste in public catering services - a case study from a Swedish municipality', Waste Management, Vol. 61, pp.415-422.

Eriksson, P. and Kovalainen, A. (2016) Qualitative Methods in Business Research, 2nd ed., Sage Publications Ltd, London.

Evans, P.C. and Gawer, A. (2016) The Rise of the Platform Enterprise: A Global Survey, The Merging Platform Economy Series, No. 1, The Center for Global Enterprise, New York, NY [online] https://www.thecge.net/app/uploads/2016/01/PDF-WEB-PlatformSurvey_01_12.pdf (accessed 21 January 2019).

FAO (2011) Global Food Losses and Food Waste - Extent, Causes and Prevention, Food and Agriculture Organization of the United Nations, Rome [online] http://www.fao.org/ docrep/014/mb060e/mb060e00.pdf (accessed 21 January 2019). 
FAO (2015) Food Wastage Footprint \& Climate Change, Food and Agriculture Organization of the United Nations, Rome [online] http://www.fao.org/3/a-bb144e.pdf (accessed 9 January 2019).

FAO (2017) Food Wastage Footprint, Food and Agriculture Organization of the United Nations, Rome [online] http://www.fao.org/nr/sustainability/food-loss-and-waste/en/ (Accessed 9 January 2019).

Gauthier, C. and Gilomen, B. (2016) 'Business models for sustainability: energy efficiency in urban districts’, Organization \& Environment, Vol. 29, No. 1, pp.124-144.

Gawer, A. (2014) 'Bridging differing perspectives on technological platforms: toward an integrative framework', Research Policy, Vol. 43, No. 7, pp.1239-1249.

Gawer, A. and Cusumano, M.A. (2014) 'Industry platforms and ecosystem innovation', Journal of Product Innovation Management, Vol. 31, No. 3, pp.417-433.

Geels, F.W. (2010) 'Ontologies, socio-technical transitions (to sustainability), and the multi-level perspective’, Research Policy, Vol. 39, No. 4, pp.495-510.

Hahn, T., Kolk, A. and Winn, M. (2010) 'A new future for business? Rethinking management theory and business strategy', Business \& Society, Vol. 49, No. 3, pp.385-401.

Hahn, T., Pinkse, J., Preuss, L. and Figge, F. (2015) 'Tensions in corporate sustainability: towards an integrative framework', Journal of Business Ethics, Vol. 127, No. 2, pp.297-316.

Heikkilä, L., Reinikainen, A., Katajajuuri, J.M., Silvennoinen, K. and Hartikainen, H. (2016) 'Elements affecting food waste in the food service sector', Waste Management, Vol. 56, pp.446-453.

Høgevold, N.M. (2011) 'A corporate effort towards a sustainable business model: a case study from the Norwegian furniture industry', European Business Review, Vol. 23, No. 4, pp.392-400.

Hörisch, J.R., Freeman, E. and Schaltegger, S. (2014) 'Applying stakeholder theory in sustainability management: links, similarities, dissimilarities, and a conceptual framework', Organization \& Environment, Vol. 27, No. 4, pp.328-346.

Katajajuuri, J.M., Silvennoinen, K., Hartikainen, H., Heikkilä, L. and Reinikainen, A. (2014) 'Food waste in the Finnish food chain', Journal of Cleaner Production, Vol. 73, pp.322-329.

Lacoste, S. (2016) 'Sustainable value co-creation in business networks', Industrial Marketing Management, Vol. 52, pp.151-162.

Landrum, N.E. (2017) 'Stages of corporate sustainability: integrating the strong sustainability worldview,' Organization \& Environment, Vol. 31, No. 4, pp.287-313.

Loorbach, D., van Bakel, J.C., Whiteman, G. and Rotmans, J. (2010) 'Business strategies for transition towards sustainable systems', Business Strategy and the Environment, Vol. 19, No. 2, pp.133-146.

Lüdeke-Freund, F. and Dembek, K. (2017) 'Sustainable business models research and practice: emerging field or passing fancy?', Journal of Cleaner Production, Vol. 168, pp.1668-1678.

Marthinsen, J., Sundt, P., Kayse, O. and Kirkevaag, K. (2012) Prevention of Food Waste in Restaurants, Hotels, Canteens and Catering, TemaNord, 537. Nordic Council of Ministers [online] http://www.diva-portal.org/smash/get/diva2:701203/FULLTEXT01.pdf (accessed 21 January 2019).

Mattila, M., Mesiranta, N., Heikkinen, A. and Turunen, S. (2018) 'Creating value from food waste: case ResQ Club’, in Dey, A.K. and Thatchenkery, T. (Eds.): Advances in Social Change, Leadership \& Organizational Decision Making, pp.13-22, Bloomsbury, New Delhi.

Närvänen, E., Mesiranta, N., Mattila, M., and Heikkinen, A. (2019) 'Introduction: a framework for managing food waste', in Närvänen, E., Mesiranta, N., Mattila, M., and Heikkinen, A. (Eds.): Solving the Wicked Problem, Palgrave Macmillan, Cham, in press. doi:10.1007/978-3-03020561-4. 
Östergren, K., Gustavsson, J., Bos-Brouwers, H., Timmermans, T., Hansen, O.-J., Møller, H., Anderson, G., O’Connor, C., Soethoudt, H., Quested, T., Easteal, S., Politano, A., Bellettato, C., Canali, M., Falasconi, L., Gaiani, S., Vittuari, M., Schneider, F., Moates, G., Waldron, K. and Redlingshöfer, B. (2014) FUSIONS: Definitional Framework for Food Waste, SIK The Swedish Institute for Food and Biotechnology, Gothenburg [online] https://www.eu-fusions.org/phocadownload/Publications/FUSIONS\%20Definitional\%20 Framework\%20for\%20Food\%20Waste\%202014.pdf (accessed 21 January 2019).

Papargyropoulou, E., Wright, N., Lozano, R., Steinberger, J., Padfield, R. and Ujang, Z. (2016) 'Conceptual framework for the study of food waste generation and prevention in the hospitality sector’, Waste Management, Vol. 49, pp.326-336.

Parfitt, J., Barthel, M., and Macnaughton, S. (2010) 'Food waste within food supply chains: quantification and potential for change to 2050', Philosophical Transactions of the Royal Society of London B: Biological Sciences, Vol. 365, No. 1554, pp.3065-3081.

Pirani, S.I. and Arafat, H.A. (2016) 'Reduction of food waste generation in the hospitality industry', Journal of Cleaner Production, Vol. 132, pp.129-145.

Priefer, C., Jörissen, J. and Bräutigam, K.R. (2016) 'Food waste prevention in Europe a cause-driven approach to identify the most relevant leverage points for action', Resources, Conservation and Recycling, Vol. 109, pp.155-165.

Ribeiro, I., Sobral, P., Peças, P. and Henriques, E. (2018) 'A sustainable business model to fight food waste', Journal of Cleaner Production, Vol. 177, pp.262-275.

Roome, N. and Louche, C. (2016) 'Journeying toward business models for sustainability: a conceptual model found inside the black box of organisational transformation', Organization \& Environment, Vol. 29, No. 1, pp.11-35.

Schaltegger, S., Hansen, E.G. and Lüdeke-Freund, F. (2016) 'Business models for sustainability: origins, present research, and future avenues’, Organization \& Environment, Vol. 29, No. 1, pp.3-10.

Schaltegger, S., Lüdeke-Freund, F. and Hansen, E.G. (2012) 'Business cases for sustainability: the role of business model innovation for corporate sustainability', International Journal of Innovation and Sustainable Development, Vol. 6, No. 2, pp.95-119.

Schor, J.B. and Attwood-Charles, W. (2017) 'The 'sharing' economy: labor, inequality, and social connection on for-profit platforms', Sociology Compass, Vol. 11, No. 8, pp.1-16.

Sharma, A. and Kearins, K. (2011) 'Interorganizational collaboration for regional sustainability: what happens when organizational representatives come together?', The Journal of Applied Behavioral Sciences, Vol. 47, No. 2, pp.168-203.

Silvennoinen, K., Heikkilä, L., Katajajuuri, J.-M. and Reinikainen, A. (2015) 'Food waste volume and origin: case studies in the Finnish food service sector’, Waste Management, Vol. 46, pp.140-145.

Sommer, A. (2012) Managing Green Business Model Transformations, Springer, Heidelberg.

Stake, R.E. (2005) 'Qualitative case studies', in Denzin, N.K. and Lincoln, Y.S. (Eds.): The Sage Handbook of Qualitative Research, 3rd ed., pp.443-466, Sage, Thousand Oaks.

Stenmarck, A., Jensen, C., Quested, T. and Moates, G. (2016) Estimates of European Food Waste Levels, IVL Swedish Environmental Research Institute, Stockholm [online] http://www.eu-fusions.org/phocadownload/Publications/Estimates\%20of\%20European\%20 food\%20waste\%20levels.pdf (accessed 21 January 2019).

Teece, D.J. (2009) Dynamic Capabilities and Strategic Management, Oxford University Press, Oxford.

United Nations (2002) The Johannesburg Declaration on Sustainable Development, A/CONF. 199/20 [online] http://www.un-documents.net/jburgdec.htm (accessed 21 January 2019).

WCED (1987) Our Common Future, World Commission on Environment and Development, Oxford University Press, Oxford. 